\title{
Spatial analysis of lanner falcon habitat preferences: Implications for agro-ecosystems management at landscape scale and raptor conservation
}

\author{
Maurizio Sarà \\ Department of Biological, Chemical and Pharmaceutical Sciences and Technologies, Palermo University, Via Archirafi 18, Italy
}

\section{A R T I C L E I N F O}

\section{Article history:}

Received 6 February 2014

Received in revised form 29 July 2014

Accepted 4 August 2014

\section{Keywords:}

Falco biarmicus feldeggii

Raptor conservation

Generalized Linear Model

Mediterranean steppe-like habitats

Collaborative agri-environment schemes,

cAES

Favourability modelling

\begin{abstract}
A B S T R A C T
Sicily hosts the largest European population of the endangered lanner falcon, a poorly known species which needs conservation planning based on habitat preferences. A distribution model on $10 \times 10 \mathrm{~km}$ cells of Sicily was described using Generalized Linear Models and variation partitioning methods. This modelling approach extracted explanatory factors, pure and joint effects of greatest influence from subsets of variables controlled for multi-collinearity and spatial autocorrelation. Analytical cartography used the environmental favourability function to assess habitat preferences, and the insecurity index estimated the degree to which lanner falcon occupancy is represented in the Natura2000 networks of Sicily. The lanner population is not randomly distributed across the geographical space as the significant latitudinal effect revealed. The most parsimonious explanatory model suggested traditional agro-ecosystems (i.e. arable lowlands and grasslands, with rugged terrains and cliffs) as the best predictors of lanner occupancy, and gave strong support to the negative effects of land abandonment and intensification (i.e. increase of heterogeneous areas and shrubby vegetation). The variation partitioning method suggested how an alteration of traditional agro-ecosystems might enhance interference competition with the peregrine falcon and limit lanner falcon occupancy. Most of the lanner falcon favourable habitats fall outside the Natura2000 networks, thus the main challenge for its conservation is represented by agri-environmental measures to be taken within the Common Agricultural Policy of the European Union. Conservation of traditional agro-ecosystems devoted to top-predators, like the lanner falcon, requires single environmental management agreements for multiple farm units, deployed at landscape scale on a network of favourable areas.
\end{abstract}

(c) 2014 Elsevier Ltd. All rights reserved.

\section{Introduction}

Complex gradients of anthropogenic disturbances and historical changes of land uses have created over millennia, the agrosylvo-pastoral landscape mosaics (=agro-ecosystems) of the Mediterranean basin (Blondel and Aronson, 1999). Actually, these human-generated open landscapes contain more specialised bird communities than forests (Clavero and Brotons, 2010), and the high species diversity and endemism of the Mediterranean basin is documented as a global biodiversity hotspot (Myers et al., 2000).

Biodiversity is one of the three priority levels for the European Union (EU), whose agricultural policies should have been adapted to halt the rate of biodiversity loss by 2010 and beyond (European Commission, 2006). Nevertheless in the last decades, expansion of the EU and its common market continued driving agricultural

E-mail address: maurizio.sara@unipa.it intensification; and the EU Common Agricultural Policy (CAP) is influencing the management of nearly half of terrestrial area of Europe, so causing vast landscape-scale changes (Pe'er et al., 2014). According to Balmford et al. (2009), intensification of farming practices in flat and coastal areas and abandonment of less productive and marginal lands, represent the main threats of agriculture on wildlife. These two opposite trends are rapidly changing friendly-to-wildlife farming systems (Brotons et al., 2004; Brambilla et al., 2008), and they will be even more enhanced, as forecasted by a range of future land-use change scenarios in the EU countries (Rounsevell et al., 2006). Changes in Mediterranean agro-ecosystems are affecting bird communities (Fonderflick et al., 2010; Sirami et al., 2008) and wildlife diversity (e.g. dung beetles, Zamora et al., 2007). Therefore, the widespread decline in European wildlife linked to agro-ecosystems currently presents a major conservation challenge (Butler et al., 2010; Green et al., 2005; Pain and Pienkowski, 1997), and understanding what 
specific land uses cause the most serious effects on wildlife and how they might evolve is required to estimate anthropogenic impacts on biodiversity of the Mediterranean basin (Donald et al., 2001; Foster et al., 2003).

The recognized broad influence of the CAP on the EU biodiversity has promoted the Rural Development Regulation (Pillar 2 of the CAP), trying to promote the maintenance of agro-ecosystems through measures designed to encourage farmers to protect and enhance habitat quality on their farmlands (Pe'er et al., 2014). Agri-environment schemes (AES) provide for payments to farmers in return for a service that is the maintenance of agricultural practices allowing the conservation of threatened species (De la Concha, 2005; European Commission, 2005). AES were introduced into EU law in the 1980s, and although designed primarily as a production control measure, they rapidly became the most important support to biodiversity in agro-ecosystems across the whole Europe (Whittingham, 2007). Depending on the species and landscape studied, AES were successful for some species and neutral for others (Batáry et al., 2011; Broyer et al., 2014; Reino et al., 2010 ), or even had negative effects (6\% of cases reviewed in Kleijn and Sutherland, 2003). Nonetheless, Kleijn and Sutherland (2003) found a positive response for biodiversity in the $54 \%$ of cases reviewed across Europe, as well as many recent studies on plant and animal diversity did (e.g. Hiron et al., 2013; KovácsHostyánszki and Báldi, 2012; Pywell et al., 2012). Despite their patchy success (Sutherland, 2004) and debates on their effectiveness (Whittingham, 2011), AES still provide the major tool to support conservation actions in agro-ecosystems (Stoate et al., 2009).

As main legislation for wildlife conservation, beside the institution of National and Local Nature Parks and Reserves, the EU has coordinated the implementation of a conservation network at a large spatial scale, namely the Natura 2000 (N2000). This protection network is based on the Birds (79/409/EEC, then amended in 2009/147/EC) and Habitats Directive of the European Union (92/43/EEC, consolidated in 2007), which focuses on the preservation of the favourable conservation status of threatened habitats, animal and plant species (as listed in the Annexes of both Directives). In many EU countries, AES implementation forms a substantial part of nature protection relative to farmed landscapes within the N2000 networks (European Commission, 2005).

Species distribution models (SDM, Guisan and Thuiller, 2005) are increasingly being used to address a wide range of questions in ecology, conservation and environmental sciences (Elith and Leathwick, 2009). In conservation biology, one major goal of regional-scale modelling is to search for anthropogenic drivers (e.g. land use change), abiotic factors (e.g. topography, climate), biotic interactions (e.g. competition), as well as historical and contingent factors that shape species distributions; with the aim to assess the impact of environmental changes and then support management plans for species recovery (Guisan and Thuiller, 2005; Rodríguez et al., 2007). Species distribution models commonly follow a correlative approach to combine species occurrence data with environmental conditions where a species is known to be present or absent, and then to build a representation of a species' ecological affinities (Guisan and Zimmermann, 2000; Franklin, 2009). Model predictions based on this approach have made a considerable contribution to identification of species-environment relationships (Bustamante and Seoane, 2004; Di Vittorio et al., 2012; Lane et al., 2001) and conservation strategies (López-López et al., 2007a,b; Poirazidis et al., 2004) for threatened avian species in Mediterranean area.

Within this context, the lanner falcon (Falco biarmicus), which is distributed across Africa, the Middle East and South-eastern Europe (Ferguson-Lee and Christie, 2001), is an ideal candidate for testing the effects of potential land use changes on wildlife and, if necessary, identifying conservation actions for threatened species in Mediterranean agro-ecosystems. The European subspecies of lanner falcon (F. b. feldeggii) is a medium-sized top predator, which inhabits Mediterranean steppe-like habitats, where it preys upon a variety of vertebrates, including diurnal and nocturnal raptors and carnivores (Massa et al., 1991). It is included in Annex I of the 2009/147/EC Bird Directive and is classified as vulnerable (Birdlife International, 2004), due to its small population and dispersal range. The largest European population of $F$. $b$. feldeggii, is found in Sicily (AA.VV., 2008; Sarà, 2008), but its range extends to continental Italy (Andreotti et al., 2008). In spite of its rarity and unfavourable conservation status, very little is known about the ecology and habitat requirements of this species (Andreotti and Leonardi, 2007).

The landscape perspective, involving the analysis of large territories, has recently been targeted as the best approach towards conservation (Pressey and Bottrill, 2009; Sanderson et al., 2002). Understanding how and where the lanner falcon occurs in a landscape that is becoming increasingly degraded and fragmented by anthropogenic pressure is a necessary prerequisite for conservation planning that aims to mitigate the population decline in its core Mediterranean range. Therefore, the first purpose of this study was to model the distribution of the lanner falcon at the landscape scale, to categorise the environmental features that best predict its habitat preferences.

As an Annex-I species, the lanner falcon would benefit from Special Protected Areas (SPAs) implemented on behalf of the Birds Directive. The Insecurity index can be used to assess the degree to which any target species is represented in an existing system of protected areas (Díaz-Gómez et al., 2013). Therefore, the second purpose of this study was to quantify how much of the regional N2000 network envelops the species' habitat preferences to further implement conservation actions.

The aims in more detail were: (i) to check whether there is a spatial structure in lanner falcon occupancy; (ii) to identify the landscape factors that influence its occupancy in Sicily; (iii) to assess whether the current regional N2000 network is adequate to preserve the population; (iv) to highlight conservation actions required to viably maintain, inside and outside the N2000 networks, the largest European population of lanner falcons.

\section{Materials and methods}

\subsection{Study area}

Sicily, the largest Mediterranean island, was selected as a study area that is representative of the lanner falcon range. It extends over an area of $25,832 \mathrm{~km}^{2}$ and is one of the most populated regions of Italy (193 inhabitants per $\mathrm{km}^{2}$ ). Almost $24.4 \%$ of the territory is mountainous, $61.4 \%$ is composed of highlands, and $14.2 \%$ of the surface is lowland. Forests and Mediterranean vegetation, of which almost $6-8 \%$ burns every year, cover $8.4 \%$ of the surface area (APAT, 2005). There is considerable habitat heterogeneity in hilly and flat inland areas, where cultivation zones (especially arable land, fodder, vineyards and olive orchards) alternate with forest patches of non-native species (Pinus spp. and Eucalyptus spp.), natural evergreen woodlands (Quercus spp.), Mediterranean xeric grasslands and shrub vegetation.

\subsection{Census and the measurement of variables at the landscape scale}

The database of lanner falcon occupancy (i.e. presence/absence) was obtained from the Atlas of Sicily (AA.VV., 2008) and from specific field surveys in the breeding territories (Andreotti and Leonardi, 2007; Di Vittorio, 2007). Together with collaborators 
well-versed in the behaviour and ecology of the lanner falcon, we monitored its population from 2000 to 2009, and we counted 122 different breeding territories; 93 of which were regularly occupied (i.e. those with individuals showing courtship behaviour, breeding attempts and chick-rearing during at least $80 \%$ of the study duration). Twenty-nine sites were excluded because they were used irregularly for breeding, were deserted or were definitely occupied by the peregrine falcon (F. peregrinus brookei). All selected territories were visited at least three times during each breeding season: from late January to early March, to check pair settlement or site desertion and to search for alternative sites nearby; from mid-March to late April during the incubation stage and from early May to mid-June during brooding and chick fledging. For the purposes of this study, the occupancy of lanner falcons was expressed in terms of territorial pairs, irrespective of reproduction and breeding success. Observations were made using binoculars and telescopes on clear days and 200-500 $\mathrm{m}$ from the nesting cliffs to avoid disturbance to the falcons.

To describe the distribution of lanner falcons at the landscape spatial scale in Sicily, the Universal Transverse Mercator (UTM) grid was employed, as it is commonly used in ornithological studies (e.g. Gregory and Baillie, 1998; Martínez et al., 2003). For the study of habitat preferences, a case-control design (Manly et al., 2002) was used. The coordinates and characteristics of the lanner falcon nest sites were recorded in the field using a Garmin GPS, identified on 1:50,000-scale maps and then assigned to a UTM cell. A digital map of nest sites was generated and is not publicly available. During the study period, some pairs moved their nest-sites to alternative ones in nearby cliffs. Very often, alternative sites were within the same UTM cell, but in case of UTM changes, the most frequently used ( $\geqslant 6$ years) UTM cell was taken during the study period as a reference for calculation. Distributional data recorded according to this protocol would reasonably minimise the risk of false absences in UTM cells.

The UTM grid divided the island's territory into $289,10 \times 10 \mathrm{~km}$ cells; 16 coastal cells with less than $2.5 \mathrm{~km}^{2}$ of land were excluded and only 273 cells were sampled and taken into consideration. Ninety-three UTM cells occupied by lanner falcons were thus compared with 180 unoccupied ones. Thirty environmental variables plus two geographic coordinates were extracted from occupied and unoccupied UTM squares (Table 1), using a Geographical Information System (ArcGIS 9.0). Three bioclimatic variables were obtained from SCIA (2008). Ecological variables were represented by the list of potential prey species of the lanner falcon, identified from regional studies (Grenci and Di Vittorio, 2004; Massa et al., 1991); whereas other local studies (Andreotti et al., 2008; Ciaccio et al., 1989) identified potential cliff competitors for the breeding space, such as corvids and other raptors. The UTM occupancies of both types of species were obtained from the Regional Atlas database (AA.VV., 2008). Altitude and slope variables were obtained from a digital elevation model (DEM) with $20 \mathrm{~m}$ pixels for horizontal and vertical resolution, provided by the Department of Environment and Land Management of Sicily. The land-use subset encompassed seven variables of land-use extents in hectares within each $10 \times 10 \mathrm{~km}$ UTM cell, as coded at the second or third hierarchical level (EEA, 2000) and acquired from GIS databases of CORINE Land Cover (CLC) digital maps (scale 1:25,000) of Sicily (http://dataservice.eea.europa.eu/dataservice). For each plot, a further subset representing quantitative land-use changes was calculated, with seven additional variables that expressed the percentage variation in land-use extents in 2006, with respect to those recorded in 2000 (i.e. = [ (area of 2006 land use $x$ - area of 2000 land use $x$ )/cell area]; cf. Table A1). Fragmentation of the landscape represented the last subset ( $n=7$ variables) and included the shape, edges and diversity measurements of land-use patches, metrically defined in Forman (1995) and McGarigal and Marks (1995), and calculated by patch analysis (Rempel et al., 2008) from CLC digital maps.

Multi-collinearity was checked, to avoid the interdependence among explanatory variables, which would hamper model selection, parameter estimation and the interpretation of results in regression analyses (Grosbois et al., 2008). A preliminary analysis of multiple correlations among the candidate variables was performed and all variables with a Variance Inflation Factor $\geqslant 5$ (i.e. Pearson $R^{2} \geqslant 0.80$; Montgomery and Peck, 1982) were excluded. The multi-collinearity tests rejected 17 variables (not reported in Table 1) from a former set of 47 potential candidates. The remaining 30 environmental variables (Table 1) therefore represent scaled and independent measures of the type and predominance of the landscape features in the study area. Accordingly, they correspond to adequate proxies for modelling the effects of the landscape composition on the lanner falcon occupancy in Sicily and are thus expected to predict the realized species distributions (Soberón, 2007).

Finally, the spatial autocorrelations among environmental variables and geographical factors were considered, because they could potentially structure the realized distribution of lanner falcons and bias ecological inference when not adequately controlled (Keitt et al., 2002; Legendre et al., 2004). Spatial structuring in species distributions might result not only from autocorrelation among environmental predictors, but also from the influence of contagious population dynamics and historical factors (Segurado et al., 2006). The latent spatial structures in the distribution of the lanner falcon were considered by incorporating two further variables, the central latitude (LAT) and longitude (LON) of each UTM cell, and making use of a third-degree polynomial equation to express the geographical coordinates of the sample locations (Legendre and Legendre, 1998; Lobo et al., 2002). A preliminary forward stepwise regression with the nine terms of the polynomial equation as predictor variables and the presence/absence of the lanner falcon as a response variable was carried out to remove non-significant spatial terms ( $P>0.05$; Carrete et al., 2007).

\subsection{Species distribution model and environmental favourability analysis}

To restrict model predictions and provide a solid application of SDMs to the problem of describing the lanner falcon distribution in Sicily, data on the presence and absence $(p / a)$ of the species were used for modelling (Guisan and Zimmermann, 2000; JiménezValverde et al., 2008), based on statistical background as more detailed in online Appendix A1.

Environmental variables were standardised (mean 0 and variance 1) to eliminate the effect of differences in the original scale of measurement. Statistical significance was set in all analyses at $P<0.05$, and means \pm standard errors (SE) were reported. Statistics were computed in STATISTICA 10.0 (www.statsoft.com).

A Generalized Linear Model (GLZ, see Hosmer and Lemeshow, 2000) was used to build a model in which the response variable was binomial $(p / a=1 / 0)$ followed by a logit link function and a binomial distribution of error structure (McCullagh and Nelder, 1989). All variables were modelled as continuous, except for the presence/absence of the peregrine falcon, which was entered in models as categorical $(p / a=1 / 0)$. The complete set of candidate predictors was separated in different subsets (Table 1 ) and independent statistical modelling procedures were performed for each subset, in order to avoid over-parameterisation and over-fitting (Grosbois et al., 2008).

Stepwise procedures are considered an effective data analysis tool when the outcome being studied is new, or the importance of individual covariates is not known (Hosmer and Lemeshow, 2000). Although the use of stepwise logistic regressions has been 
Table 1

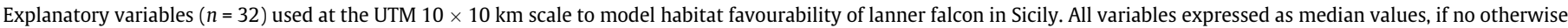
specified. Land uses are expressed in hectares and refer to CORINE Land Covers (CLC) with current EEA (2000) codes between brackets.

\begin{tabular}{|c|c|c|}
\hline Predictor set & Code & Variable \\
\hline Spatial coordinates $n=2$ & $\begin{array}{l}\text { LON } \\
\text { LAT }\end{array}$ & $\begin{array}{l}\text { Central longitude }\left({ }^{\circ} \mathrm{E}\right) \\
\text { Central latitude }\left({ }^{\circ} \mathrm{N}\right)\end{array}$ \\
\hline Topographic $n=5$ & $\begin{array}{l}\text { SLO_m } \\
\text { SLO_r } \\
\text { ALT_r }\end{array}$ & $\begin{array}{l}\text { Mean slope } \\
\text { Range of slope (min-max) } \\
\text { Range of altitude above sea level }\end{array}$ \\
\hline Bioclimatic $n=3$ & $\begin{array}{l}\text { BCI } \\
\text { DAI } \\
\text { AAR }\end{array}$ & $\begin{array}{l}\text { Bioclimatic index of Rivas-Martínez (1988) } \\
\text { De Martonne aridity index } \\
\text { Annual accumulated rainfall (mm) }\end{array}$ \\
\hline Ecological $n=3$ & $\begin{array}{l}\text { p/a_FPER } \\
\text { S_PREY } \\
\text { S_CLIFF }\end{array}$ & $\begin{array}{l}\text { Presence/absence of peregrine falcon (Falco peregrinus brookei) } \\
\text { Number of potential lanner prey species } \\
\text { Number of cliff dwellers species (Raptors and Corvids) }\end{array}$ \\
\hline Land use extent $n=7$ & $\begin{array}{l}\text { ART } \\
\text { ARA } \\
\text { PER } \\
\text { HET } \\
\text { FOR } \\
\text { SHR } \\
\text { GRZ }\end{array}$ & $\begin{array}{l}\text { Urban fabrics, Artificial soil and infrastructures }(11,12,13,14) \\
\text { Arable land (21) } \\
\text { Permanent crops }(22) \\
\text { Heterogeneous agricultural areas }(24) \\
\text { Forests and woodlands }(31) \\
\text { Shrubby vegetation associations }(322,323,324) \\
\text { Natural grasslands and sparsely vegetated areas }(321,333)\end{array}$ \\
\hline Land use change $n=7$ & $\begin{array}{l}\text { ART_var } \\
\text { ARA_var } \\
\text { PER_var } \\
\text { HET_var } \\
\text { FOR_var } \\
\text { SHR_var } \\
\text { GRZ_var }\end{array}$ & $\begin{array}{l}2000-06 \text { variation (\%) of artificial land use area } \\
2000-06 \text { variation (\%) of arable land area } \\
\text { 2000-06 variation (\%) of permanent crop extension } \\
2000-06 \text { variation (\%) of heterogeneous agricultural areas } \\
2000-06 \text { variation (\%) of forests } \\
2000-06 \text { variation (\%) of shrubby vegetation associations } \\
2000-06 \text { variation (\%) of grasslands and sparsely vegetated areas }\end{array}$ \\
\hline Habitat mosaic $n=7$ & $\begin{array}{l}\text { SDI } \\
\text { S } \\
\text { PRD } \\
\text { MPS } \\
\text { MSI } \\
\text { MPE } \\
\text { ED }\end{array}$ & $\begin{array}{l}\text { CLC shannon diversity index } \\
\text { Number of CLCs } \\
\text { Patch richness density } \\
\text { Mean patch size } \\
\text { Mean shape index } \\
\text { Mean patch edge } \\
\text { Edge density of patches }\end{array}$ \\
\hline
\end{tabular}

criticised (Whittingham et al., 2006), they have been broadly used (Pearce and Ferrier, 2000; Thuiller, 2003) and still considered able to increase the explanatory power of models (Murtaugh, 2009). For each logistic regression model, a forward stepwise procedure was initially used, including all variables and their interactions in a given subset at once and the removal of non-significant variables (Wald's test, $P$ to enter $=0.05 ; P$ to remove $=0.05, n=100$ iterations). As a second step, the explanatory power of each independent logistic model was compared, using an information theoretic approach involving Akaike's information criterion (AIC; Akaike, 1973). All models were evaluated by ranking those from the lowest (best) to the highest (worst), computing the difference between each model's AIC value and that of the lowest model $(\triangle \mathrm{AIC})$. Finally, the Akaike model weight (AICW), which averages the ranked models, so that the sum of weights over the set of candidate models is 1 (Conroy and Carroll, 2009) was obtained. If two models differed by less than two AIC points, they were considered to receive nearly identical support from the data (Burnham and Anderson, 2002). As a final step, the above procedures were repeated, considering only the significant explanatory variables with the lowest AIC values, to extract the final subset that best predicts the occupancy of lanner falcons (Murtaugh, 2009). Over 1200 combinations of these significant variables hold in pairs, trios, etc, were evaluated and ranked by AIC to find the final model with the best explanatory power.

Logistic regression equations usually employed in habitat preference modelling compute probability values based not only on the values of the predictor variables, but also on the relative proportion of individual presences and absences within the dataset. In cases of high prevalence of absences, as in the lanner falcon dataset here (180 absences out of 273 UTM cells), the logistic regression does not adequately describe the species' environmental suitability; therefore a favourability function not conditioned by the presence/absence ratio (Real et al., 2006) was used. This modification of logistic regression assesses the variation in the probability of occurrence of species in certain local conditions, with respect to the overall species prevalence; so that favourability values reflect only the environmental conditions that are appropriate for the species (Acevedo and Real, 2012). Favourability values were obtained from the probability values yielded by the logistic regression in this way:

$F=\frac{P /(1-P)}{n_{1} / n_{0}+P /(1-P)}$

where $P$ is the logistic probability value, $n_{1}$ is the number of presences and $n_{0}$ the number of absences (see details in Real et al., 2006). The environmental threshold was set at $F=0.5$ to average the species' prevalence over the entire sample area.

To assess the classification accuracy of the models, the values of a confusion matrix were used to calculate the correct classification rate (CCR), sensitivity (the ratio of correctly predicted presences to the total number of presences), specificity (the ratio of correctly predicted absences to the total number of absences), and the Area Under the Curve (AUC) of the Receiver Operating Characteristic, which is a measure of the overall probability that a presence site has higher predicted favourability than an absence site. Again, the favourability classification threshold was set at $F=0.5$, as the best compromise to minimize the difference between sensitivity and specificity; and for species, like the lanner falcon, which have relatively restricted range (Barbosa et al., 2013). In addition, four new measures that complete the scrutiny of distribution model 
predictions were used (Barbosa et al., 2013). The under-prediction and over-prediction rates (UPR and OPR, respectively) assess prediction mismatch in SDMs from the perspective of the predicted rather than observed data. Model equilibrium between the observed and the potential area of occupancy have been measured by the potential presence and absence increments (PPI and PAI, respectively).

A variation partitioning procedure (Legendre and Legendre, 1998; Lobo et al., 2002) was performed to identify how much of the variation of the final model was explained exclusively by each factor (i.e. pure effect, $R_{\mathrm{pi}}^{2}$ ), and how much was attributable to their joint effects (i.e. intersection, $R^{2}{ }_{i j}$ ). The total variation within the occupancy of the lanner falcon was decomposed among three groups of explanatory variables ( $p / a$ of the peregrine falcon, topography, land-use extent and change) obtained from the final model. The proportion of the variation explained, as pure effect and intersection, by each group of explanatory variables was obtained by performing logistic regressions of lanner falcon $p / a$ data on the final model and on pair-wise combinations of the three explanatory groups. Then, the values obtained in the final model were regressed on those yielded by: (i) the three single groups; (ii) the three combinations of two groups (e.g., $p / a$ peregrine falcon plus topography, etc); and (iii) the three groups taken together. This allowed to assess the variation attributable to any pure and intersection effect by subtraction of the adjusted Pearson coefficients of determination (e.g. for intersection of $i$ and $j: R^{2}{ }_{i j}=R^{2}{ }_{i+j}-\left(R_{\mathrm{pi}}^{2}+R_{\mathrm{pj}}^{2}\right)$; see details in Legendre and Legendre, 1998 pp. 529-538; and Muñoz et al., 2005).

\subsection{Mapping environmental favourability}

The area occupied by the lanner falcon that was classified as favourable after modelling its occupancy, was used to evaluate the degree to which the lanner falcon is represented in the existing N2000 areas and to further identify areas of conservation importance for future conservation efforts. Favourability values for the lanner falcon in each UTM cell indicate how the local probability of presence differs from that expected by chance in the whole study area, taking 0.5 as the threshold above which presence is more likely than absence (Real et al., 2006). To establish unambiguously differences between favourable and unfavourable cells (Hosmer and Lemeshow, 2000; Real et al., 2006) the favourability values obtained for each $10 \times 10 \mathrm{~km}$ UTM cells were distinguished into three classes: $<0.20$ (unfavourable, i.e. with odds less than $1: 4)$; $0.20-0.80$ (intermediate favourability, with intermediate odds); and $>0.80$ (favourable, i.e. with odds more than $4: 1$ ). Once the analytical cartography was generated, the overall Insecurity index of the lanner falcon, which represents the proportion of the fuzzy set of favourable areas for that species not included in the fuzzy set of protected areas (Díaz-Gómez et al., 2013) was measured.

In Sicily (http://www.artasicilia.eu/old_site/web/natura2000/ index.html), 196 areas (172 Sites of Community Interests (SCI), 11 Special Protection Areas (SPA) and 13 SPA/SCIs) encompass the N2000 networks suitable for the lanner falcon, once excluded marine, beach and strictly coastal protected areas. Two networks were independently considered: (i) the ensemble of SPAs and SPA/SCIs specifically designated to protect birds under the Birds Directive, here-to-after the SPA network; (ii) the total regional ensemble of protected areas (i.e., Regional Parks and Reserves, SCIs, SPAs and SPA/SCIs), here-to-after the ALL network. Firstly, the vector map on protected areas was intersected with the UTM projected grid of Sicily. For each polygon of the UTM projected grid, the intersected areas were used to calculate the proportion of the polygon covered by protected areas $(\mathrm{Pj})$. $\mathrm{Pj}$ ranges between 0 and 1 , with a polygon receiving a value of 1 when is completely covered by protected areas. Then the extent and percentage of both networks of protected areas in the collection of 273 UTM cells were statistically correlated to favourability values of the same cells, and used to obtain Insecurity indexes (0-1) for the lanner falcon. Insecurity indexes were calculated at UTM cell level and then averaged to the collection of UTM cells representing Sicily to obtain the overall Insecurity index and its upper and lower confidence limits at 95\% (UCL95\% and LCL95\%) for both SPA and ALL networks (Díaz-Gómez et al., 2013).

\section{Results}

\subsection{Lanner distribution model}

The occupancy of lanner falcons had a significant geographical effect, as the stepwise GLZ selected the latitude (Wald statistic $=18.663 ; P=0.00002)$ and its interaction with longitude (Wald statistic $=15.477 ; P=0.00008)$. This significant geographical effect was retained in modelling each subset (Table 2). With regards to the topographic subset, the GLZ showed that the probability of finding a UTM cell occupied by lanner falcons increases with the mean slope (SLO_m), but decreases with the interactions between the mean slope and latitude (SLO_m $\times$ LAT), and between the mean slope and altitude range (SLO_m $\times$ ALT_r); the altitude range (ALT_r), the interaction between the altitude range and latitude $($ ALT_r $\times$ LAT) and between latitude and longitude (LAT $\times$ LON). In the bioclimatic subset, both the negative effect of interaction between the bioclimatic index and latitude $(\mathrm{BCI} \times \mathrm{LAT})$ and again LAT and LAT $\times$ LON, were selected, the first coordinate with a positive effect and the second with a negative effect on lanner falcon occupancy (Table 2). In the ecological subset, LAT and LAT $x$ LON were also selected with the same effects as above, together with the negative effect of the presence of peregrine falcons. Several single land-use variables, such as the extent of arable areas (ARA), natural grasslands and sparsely vegetated areas (GRZ), heterogeneous agricultural areas (HET), and forests and woodlands (FOR), as well as the interaction between arable and natural grasslands $($ ARA $\times$ GRZ) increased the probability of lanner falcon occupancy, whereas the interaction between arable and heterogeneous agricultural areas $($ ARA $\times$ HET) and that of latitude and longitude decreased such probability. Modelling the land-use change in 2000-2006 yielded the positive effect of latitude in the variation of natural grasslands and sparsely vegetated areas (GRZ_var $\times$ LAT) on the probability of lanner falcon occupancy; contrariwise to the negative effect of variation in permanent crops (PER_var), of interaction between the variation of heterogeneous agricultural areas and shrubby vegetation associations (HET_var $\times$ SHR_var), and of latitude and longitude. The habitat mosaic subset (Table 2) provided the selection of the interaction between mean shape index and mean patch size (MSI $\times$ MPE), and that of the number of CLCs and latitude $(\mathrm{S} \times \mathrm{LAT})$, both with negative effects on lanner falcon occupancy, together with the usual effects of LAT and LAT $\times$ LON.

The AIC values for each model ranged from 276.354 to 321.154 (Table 3). The lowest AIC value was obtained for the land-use model that therefore ranked first $(\triangle \mathrm{AIC}=0.0)$ with the highest AICW (0.9997). The second topographic model ranked outside the 2 AIC values $(\triangle \mathrm{AIC}=16.249)$ and had a negligible weight $(\mathrm{AICW}=2.961 \mathrm{E}-04$. The bioclimatic model ranked in the last place, with the worst performance. The discrimination performances of these models are also shown in Table 3. For every model, sensitivity, specificity, CCR and AUC measured the proportion of observations that are correctly predicted; whereas UPR and OPR measured the proportion of predictions that are not matched by observations; PPI and PAI measured the model equilibrium between potential and observed occupancy with respect to the reference absence of differences (i.e. reference PPI and PAI $=0$ ). The 
Table 2

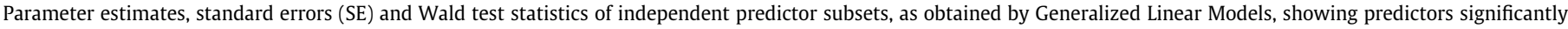
affecting the probability of lanner falcon occupancy in Sicily at landscape scale.

\begin{tabular}{|c|c|c|c|c|c|}
\hline Subset & Variable & Estimate & SE & Wald & $p$ \\
\hline Topographic & $\begin{array}{l}\text { Intercept } \\
\text { SLO_m } \\
\text { SLO_m } \times \text { LAT } \\
\text { SLO_m } \times \text { ALT_r } \\
\text { ALT_r } \\
\text { ALT_r } \times \text { LAT } \\
\text { LON } \times \text { LAT }\end{array}$ & $\begin{array}{l}-0.405 \\
1.478 \\
-0.064 \\
-0.733 \\
-1.042 \\
-0.733 \\
-2.094\end{array}$ & $\begin{array}{l}0.218 \\
0.407 \\
0.374 \\
0.521 \\
0.473 \\
0.521 \\
1.351\end{array}$ & $\begin{array}{r}3.463 \\
19.443 \\
3.936 \\
11.479 \\
4.979 \\
9.291 \\
12.837\end{array}$ & $\begin{array}{l}0.063 \\
0.000 \\
0.047 \\
0.001 \\
0.026 \\
0.002 \\
0.000\end{array}$ \\
\hline Bioclimatic & $\begin{array}{l}\text { Intercept } \\
\text { BCI } \times \text { LAT } \\
\text { LAT } \\
\text { LON } \times \text { LAT }\end{array}$ & $\begin{array}{l}-0.570 \\
-0.419 \\
2.409 \\
-3.027\end{array}$ & $\begin{array}{l}0.199 \\
0.321 \\
1.213 \\
1.236\end{array}$ & $\begin{array}{r}8.180 \\
5.206 \\
7.734 \\
11.029\end{array}$ & $\begin{array}{l}0.004 \\
0.023 \\
0.005 \\
0.001\end{array}$ \\
\hline Ecological & $\begin{array}{l}\text { Intercept } \\
\text { p/a_FPER } \\
\text { LAT } \\
\text { LON } \times \text { LAT }\end{array}$ & $\begin{array}{l}-0.715 \\
-0.365 \\
3.677 \\
-4.069\end{array}$ & $\begin{array}{l}0.202 \\
0.192 \\
1.115 \\
1.133\end{array}$ & $\begin{array}{l}12.524 \\
14.429 \\
12.845 \\
14.921\end{array}$ & $\begin{array}{l}0.000 \\
0.000 \\
0.000 \\
0.000\end{array}$ \\
\hline Land use extent & $\begin{array}{l}\text { Intercept } \\
\text { ARA } \\
\text { GRZ } \\
\text { ARA } \times \text { GRZ } \\
\text { ARA } \times \text { HET } \\
\text { HET } \\
\text { HET } \times \text { LAT } \\
\text { FOR } \\
\text { LON } \times \text { LAT }\end{array}$ & $\begin{array}{l}-0.445 \\
1.905 \\
0.463 \\
1.122 \\
-0.863 \\
0.394 \\
-0.369 \\
1.315 \\
-0.613\end{array}$ & $\begin{array}{l}0.343 \\
0.542 \\
0.393 \\
0.438 \\
0.326 \\
0.324 \\
0.295 \\
0.550 \\
2.067\end{array}$ & $\begin{array}{r}1.686 \\
30.628 \\
15.079 \\
7.410 \\
7.228 \\
6.788 \\
4.002 \\
3.967 \\
9.700\end{array}$ & $\begin{array}{l}0.194 \\
0.000 \\
0.000 \\
0.006 \\
0.007 \\
0.009 \\
0.045 \\
0.046 \\
0.002\end{array}$ \\
\hline Land use change & $\begin{array}{l}\text { Intercept } \\
\text { PER_var } \\
\text { HET_var } \times \text { SHR_var } \\
\text { GRZ_var } \times \text { LAT } \\
\text { LAT } \\
\text { LON } \times \text { LAT }\end{array}$ & $\begin{array}{l}-0.629 \\
-0.163 \\
-0.487 \\
0.686 \\
4.725 \\
-5.594\end{array}$ & $\begin{array}{l}0.271 \\
0.308 \\
0.271 \\
0.304 \\
1.521 \\
1.560\end{array}$ & $\begin{array}{r}5.406 \\
3.900 \\
7.086 \\
6.723 \\
11.627 \\
16.171\end{array}$ & $\begin{array}{l}0.020 \\
0.048 \\
0.008 \\
0.010 \\
0.001 \\
0.000\end{array}$ \\
\hline Habitat mosaic & $\begin{array}{l}\text { Intercept } \\
\mathrm{S} \times \text { LAT } \\
\text { MPS } \times \text { MSI } \\
\text { LAT } \\
\text { LON } \times \text { LAT }\end{array}$ & $\begin{array}{l}-0.662 \\
-2.242 \\
-2.210 \\
2.780 \\
-3.158\end{array}$ & $\begin{array}{l}0.759 \\
1.221 \\
2.244 \\
1.455 \\
1.474\end{array}$ & $\begin{array}{r}0.760 \\
4.419 \\
5.696 \\
11.613 \\
14.204\end{array}$ & $\begin{array}{l}0.383 \\
0.036 \\
0.017 \\
0.001 \\
0.000\end{array}$ \\
\hline Final best subset & $\begin{array}{l}\text { Intercept } \\
\text { p/a_FPER } \\
\text { SLO_m } \\
\text { ALT_r } \\
\text { ARA } \\
\text { ARA } \times \text { HET } \\
\text { ARA } \times \text { GRZ } \\
\text { HET_var } \times \text { SHR_var } \\
\text { GRZ_var } \times \text { LAT } \\
S \times \text { LAT }\end{array}$ & $\begin{array}{l}-1.151 \\
-0.865 \\
1.191 \\
-0.835 \\
1.236 \\
-0.572 \\
0.579 \\
-0.625 \\
0.466 \\
-0.816\end{array}$ & $\begin{array}{l}0.213 \\
0.195 \\
0.342 \\
0.388 \\
0.225 \\
0.238 \\
0.230 \\
0.216 \\
0.202 \\
0.210\end{array}$ & $\begin{array}{r}29.353 \\
19.614 \\
12.136 \\
4.647 \\
30.111 \\
5.802 \\
6.327 \\
8.380 \\
5.328 \\
15.058\end{array}$ & $\begin{array}{l}0.000 \\
0.000 \\
0.000 \\
0.031 \\
0.000 \\
0.016 \\
0.012 \\
0.004 \\
0.021 \\
0.000\end{array}$ \\
\hline
\end{tabular}

land-use extent model was confirmed as the best one to describe the occupancy of the lanner falcon, because it showed the relatively highest sensitivity, specificity, AUC and CCR and the lowest UPR values. Mismatches of remaining models were, however, relatively acceptable ranging between 0.172 and 0.383 for UPR; and between 0.244 and 0.536 for OPR. After the land-use extent model, the topographic and ecological models were the second and third, respectively most in equilibrium, due to their relatively lower PPI and PAI (Table 3).

Despite their large drop in $\triangle \mathrm{AICs}$ and negligible AICW, some models (e.g., topographic, ecological) showed a comparable discrimination performance with respect to the highest-ranked model. In addition, the geographical effect of latitude and its interaction with longitude was recurrent in all models. Therefore, to unravel the effects of the geographical variables and other single explanatory variables contained within each of the six models, logistic regressions were repeated with the significant variables previously extracted. The best subset of explanatory variables predicting the occupancy of the lanner falcon selected a mix of nine variables from all subsets except for the bioclimatic one and is also shown in Table 2. These variables are: three land uses (ARA, ARA $\times$ GRZ, ARA $\times$ HET), two topographic (SLO_m and ALT_r), two land-use changes (HET_var $\times$ SHR_var, GRZ_var $\times$ LAT), one habitat mosaic $(\mathrm{S} \times \mathrm{LAT})$ and one ecological ( $p / a$ peregrine). The final best subset had a lower AIC (240.611) with respect to the land-use extent model alone, and improved the estimates of correctly predicted observations (specificity $=0.789$; $C C R=0.795$ and AUC $=0.883$ ). In addition, the final best subset had a lower mismatch between predictions and observations (UPR $=0.113$ and $\mathrm{OPR}=0.336$ ) and the most acceptable equilibriums between potential and observed occupancies ( $\mathrm{PPI}=0.215$ and $\mathrm{PAI}=-0.111$; Table 3). For two measures (sensitivity and UPR), the land-use extent model outperformed the final best subset. The results of the model variation partitioning (Fig. 1) indicate that $55.6 \%$ of variation within the final model is accounted for by the pure effect of total land uses (i.e. considering extent, change and CLC number all together); $6.9 \%$ is explained by the pure effect of $p / a$ of the peregrine falcon; and $1.1 \%$ by the pure effect of topography. The joint effect between topography and $p / a$ of the peregrine falcon $(18.8 \%)$ was the strongest combination between groups of 
Table 3

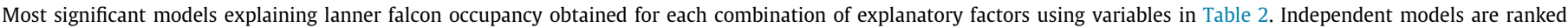

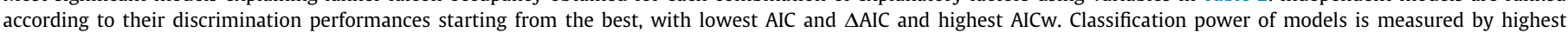

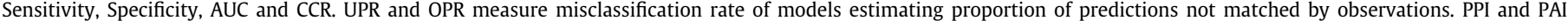
measure equilibrium between the model and the species' distribution.

\begin{tabular}{|c|c|c|c|c|c|c|c|}
\hline & Land use extent & Topographic & Ecological & Land use change & Habitat mosaic & Bioclimatic & Final best subset \\
\hline $\mathrm{DF}$ & 8 & 6 & 3 & 5 & 4 & 3 & 9 \\
\hline AIC & 276.354 & 292.603 & 311.828 & 314.698 & 315.997 & 321.154 & 240.611 \\
\hline$\Delta \mathrm{AIC}$ & 0 & 16.249 & 35.474 & 38.344 & 39.643 & 44.8 & 0 \\
\hline $\mathrm{AICw}$ & 0.9997 & $2.96 \mathrm{E}-04$ & $1.98 \mathrm{E}-08$ & $4.72 \mathrm{E}-09$ & $2.46 \mathrm{E}-09$ & $1.87 \mathrm{E}-10$ & $0.536^{\mathrm{a}}$ \\
\hline Sensitivity & 0.828 & 0.731 & 0.710 & 0.720 & 0.493 & 0.763 & 0.807 \\
\hline Specificity & 0.756 & 0.667 & 0.650 & 0.600 & 0.837 & 0.544 & 0.789 \\
\hline UPR & 0.105 & 0.172 & 0.188 & 0.194 & 0.383 & 0.183 & 0.113 \\
\hline OPR & 0.364 & 0.469 & 0.488 & 0.518 & 0.244 & 0.536 & 0.336 \\
\hline PPI & 0.301 & 0.376 & 0.387 & 0.495 & -0.348 & 0.645 & 0.215 \\
\hline PAI & -0.156 & -0.194 & -0.200 & -0.256 & 0.356 & -0.333 & -0.111 \\
\hline CCR & 0.780 & 0.689 & 0.670 & 0.641 & 0.663 & 0.619 & 0.795 \\
\hline AUC & 0.834 & 0.790 & 0.746 & 0.734 & 0.729 & 0.719 & 0.883 \\
\hline
\end{tabular}

AIC = Akaike's Information Criterion.

$\triangle \mathrm{AIC}=\mathrm{AIC}$ differences from the first ranked model.

AICW $=$ AIC weight.

AUC $=$ area under curve.

$\mathrm{CCR}=$ correct classification rate.

$\mathrm{UPR}=$ under-prediction rate.

$\mathrm{OPR}=$ over-prediction rate.

PPI = potential presence increment.

$\mathrm{PAI}=$ potential absence increment.

$\mathrm{DF}=$ degree of freedom.

a AICw calculated with respect to the second ranked best subset model (AIC $=243.566 ; \Delta$ AIC 3.0 ; $D F=8$ ) which is identical to the first but lacks ALT_r ( cf. Table 2, final best subset).

explanatory factors, followed by the joint effect between topography and land-use variables (15.3\%) and then by the joint effect between total land-uses and $p / a$ of the peregrine falcon (10.9\%). The joint combination of three groups had a negative value $(-8.8 \%)$, meaning that all nine variables contained within the best subset have strong opposing effects on the occupancy of lanner falcons in the landscape.

\subsection{Mapping lanner environmental favourability}

Analytical cartography for lanner falcon occupancy, as derived from the nine explanatory variables selected in the best subset model and scaled from unfavourable to favourable values (0-1) is represented in Fig. 2, which also shows the shapes of all protected areas forming the N2000 networks of Sicily. Visual inspection of Fig. 2 already allows an awareness of the mismatch among shapes of the protected area systems and the UTM cells with favourable values $(F>0.80)$; as confirmed by the negative statistical correlation between the extent of all areas in the N2000 network and favourability values in UTM cells ( $\tau$ Kendall $=-0.09$; $P<0.05$; Fig. A1). The overall Insecurity indexes calculated over the SPA network $(I=0.903$; LCL-UCL 95\% $=0.894-0.910)$ and over the ALL areas network ( $I=0.834$; LCL-UCL 95\% $=0.820-0.840)$ quantified the great proportion of the set of favourable areas for the lanner falcon which is not included in the two networks. Most of such areas are located in open landscapes and agro-systems of western and central Sicily; outside from, or contouring large N2000 sites and Regional parks located mostly in north-eastern and south-eastern of Sicily (Fig. 2).

The study area represents $96.7 \%$ of whole of Sicily and the current N2000 network sampled in the study area is slightly smaller $(<1 \%)$ than the whole network of Sicily. Arable land, natural grassland and other steppe-like areas belonging to favourable agroecosystems for the lanner falcon encompass around 1,000,000 ha, representing $42 \%$ of the study area (Table 4 ). Approximately one third of these agro-ecosystems (34\%) fall within UTM cells with high environmental favourability, $46 \%$ within the intermediate

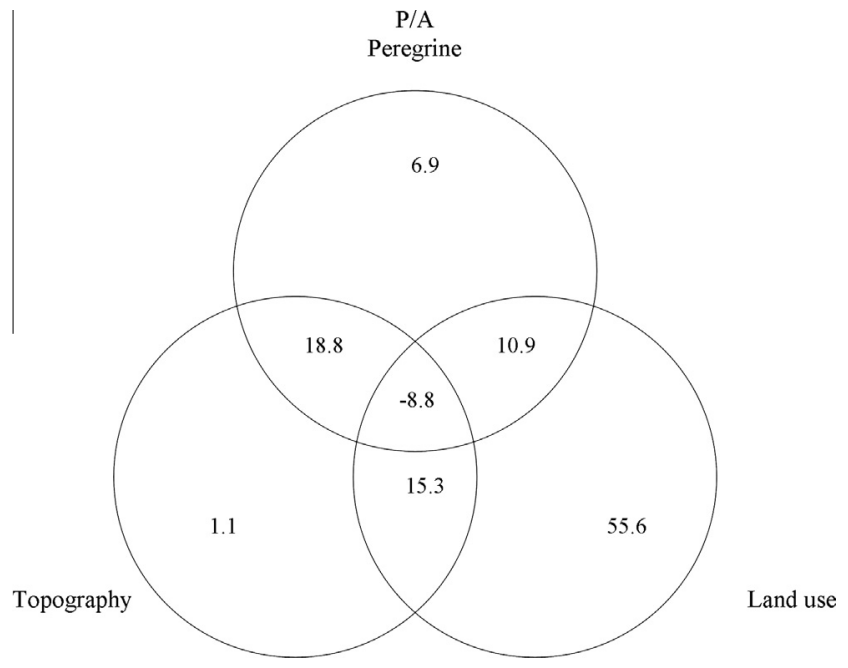

Fig. 1. Values shown in the Venn diagram are the percentage of variation obtained by partitioning the total sum of squared deviation of the response variable for each pure and intersection effect of final model. $P / A$ peregrine $=$ effect of presence/ absence in the UTM cell of peregrine falcon; Topography = effects of slope mean plus altitudinal range; Land use = effects of land uses extent (ARA, ARA x HET, ARA x GRZ), plus variation of land use extent in 2000-2006 (HET_var $\times$ SHR_var, GRZ_var $\times$ LAT) and latitudinal variation of land uses richness $(\mathrm{S} \times \mathrm{LAT})$.

favourability category, and the remaining $20 \%$ within unfavourable cells. Yet, a little more than $50 \%$ of lanner falcon occupancy (50 out 93 UTM cells) corresponds to UTM cells with environmental favourability. Total extent of protected areas with environmental favourability for the lanner falcon are around 45,000 ha of the SPA network, and 76,000 ha of the ALL N2000 network, thus corresponding to a little $2-3 \%$ of Sicily. On average $7.93 \%$ and $13 \%$ of each UTM cell extent is protected, under the SPA and ALL network, respectively (Table 4 ). Those figures are very low with respect the corresponding extents (some 500,000 ha in both networks) and averages (some $90 \%$ of cell extents in both networks) of areas still unsecure and unprotected but classified as environmentally 
favourable. The intermediate environmental favourability category has also important figures, hosting 40 of the lanner falcon occupancy cells and relatively higher extents and percentages of protected areas in both N2000 networks.

\section{Discussion}

Occupancy data were used to discriminate the environmental factors capable of explaining the potentially favourable habitats for the lanner falcon in a Mediterranean landscape. A good fit of a model does not necessarily imply a straight causal relationship between species distribution and the selected habitat predictors (Austin et al., 1996). Nonetheless, the modelling procedure suggested that a limited number of topographical, human-related and ecological variables might describe lanner falcon occupancy in the study area.
The population of lanner falcons in Sicily is not randomly distributed across space, as indicated by the significant spatial autocorrelation effect of latitude, its interaction with longitude and with some other significant predictors, across independent modelling. The retention of such spatial component suggests that the species distribution is most probably related to geographical or historical factors or to processes of population dynamics (Legendre and Legendre, 1998). The geographical effect might actually be the most convincing explanation, as more occupied cells exist in south-western, southern and central areas than other parts of the island. The spatial signal would thus coincide with the geographical distribution of suitable sites and the aggregation of the occupation cells (Sarà, 2008).

The parsimonious GLZ explanatory model suggested that the most favourable habitats for the lanner falcon are large steppe-like areas at low altitudes, with large mean slope values. A preference

$1: 1.200 .000$

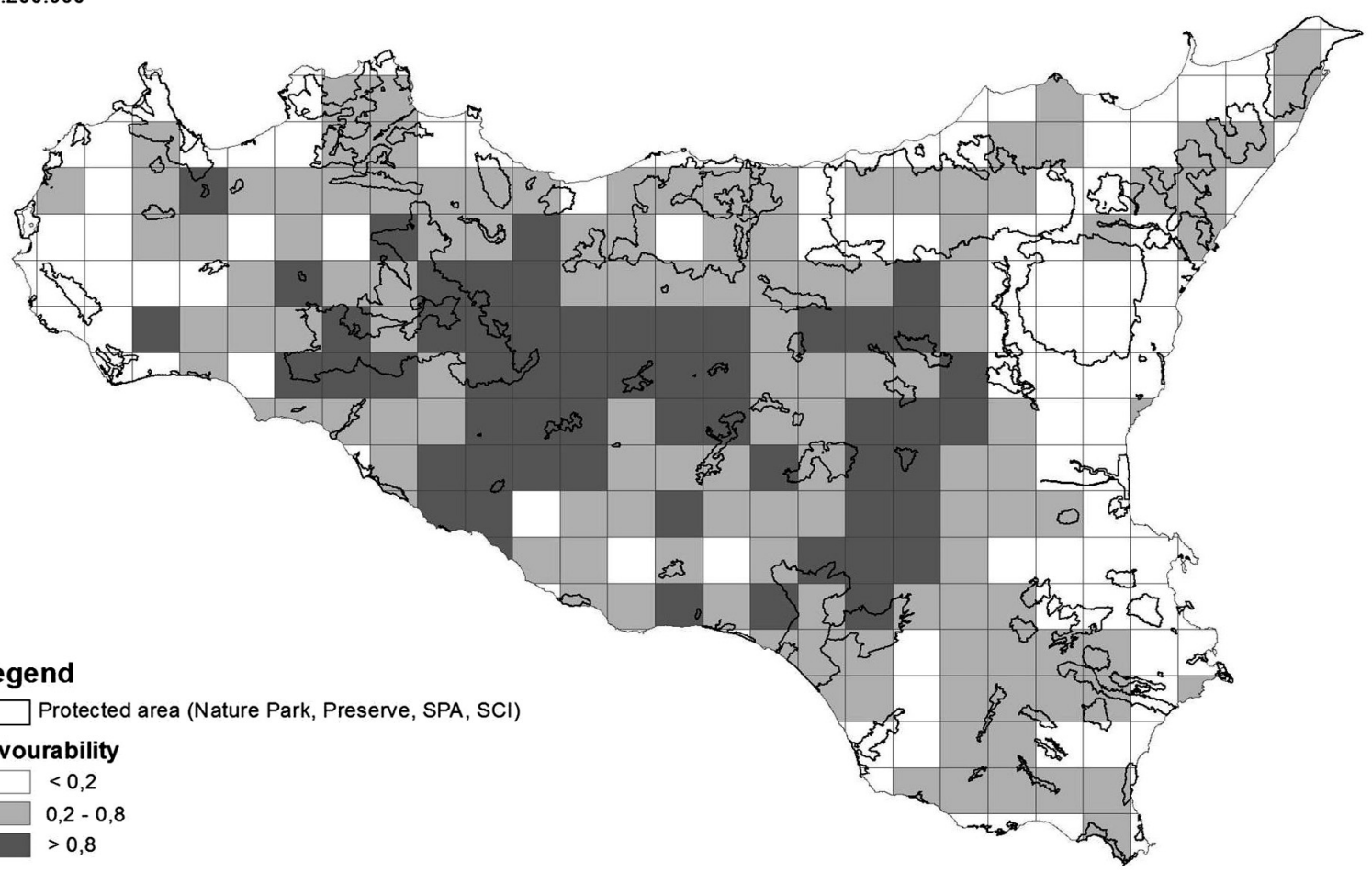

$1: 1.200 .000$

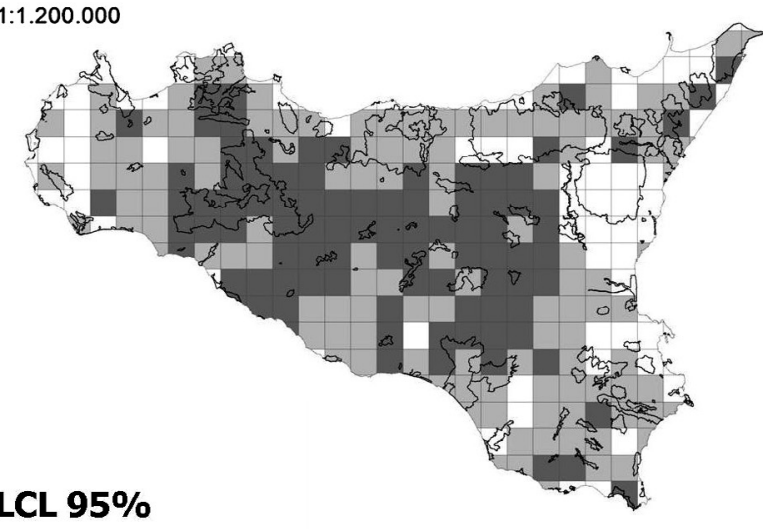

$1: 1.200 .000$

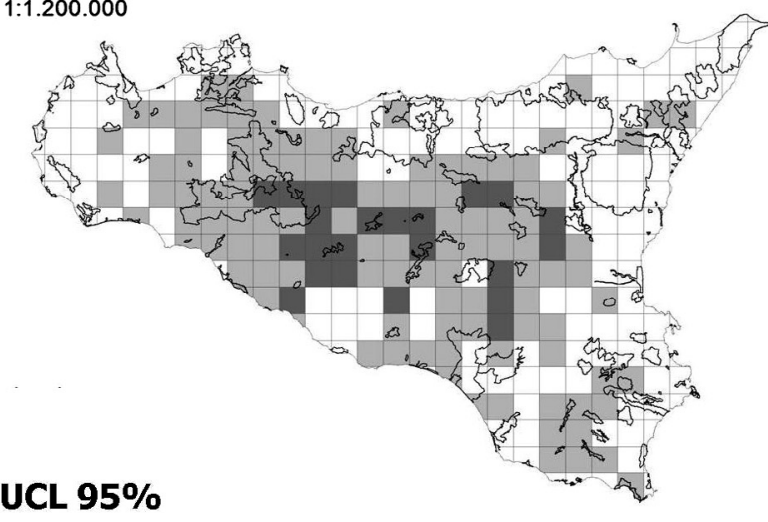

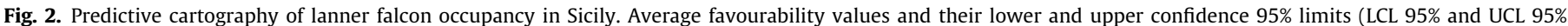

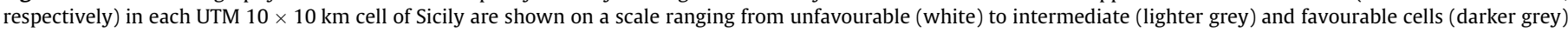
and superimposed to the total ensemble of Natura 2000 network (SPA, SCI, SPA/SCI, Park, Preserves). 
Table 4

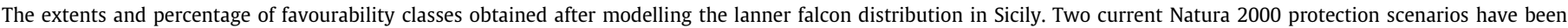

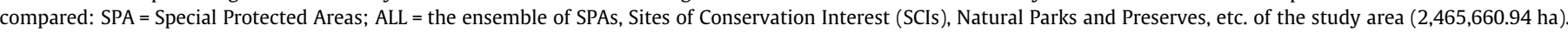

\begin{tabular}{|c|c|c|c|c|}
\hline & Favourable $F>0.80$ & Intermediate favourability $F=0.20-0.80$ & Unfavourable $F<0.20$ & Total \\
\hline Total extent of cereal steppes & 352850.08 & 473623.35 & 210558.33 & 1037031.75 \\
\hline Lanner falcon occupancy (N UTM) & 50 & 40 & 3 & 93 \\
\hline \multicolumn{5}{|l|}{ SPA network } \\
\hline Total extent of protected areas & 45187.04 & 143190.70 & 67211.19 & 255588.93 \\
\hline Mean percentage of protected areas in UTM cells & 7.93 & 12.39 & 9.54 & \\
\hline Total extent of unprotected areas & 512686.29 & 1041967.17 & 655418.55 & 2210072.01 \\
\hline Mean percentage of unprotected areas in UTM cells & 92.07 & 87.61 & 90.46 & \\
\hline \multicolumn{5}{|l|}{ ALL network } \\
\hline Total extent of protected areas & 76465.72 & 246168.33 & 169663.49 & 492297.54 \\
\hline Mean percentage of protected areas in UTM cells & 13.00 & 21.13 & 21.79 & \\
\hline Total extent of unprotected areas & 483792.02 & 936504.29 & 553021.64 & 1973317.95 \\
\hline Mean percentage of unprotected areas in UTM cells & 87.00 & 78.87 & 78.21 & \\
\hline
\end{tabular}

for a low altitudinal range might be related to the distribution of hot pseudo-steppes in thermo-Mediterranean climate (Goriup, 1988), thus confirming the preference of $F$. b. feldeggii for dry and warm habitats (Ferguson-Lee and Christie, 2001), or for semi-desert environments as in the Caucasus (Abuladze et al., 1991). Mean slope values probably relate to the presence of rugged terrains and hence to cliff availability (Balbontín, 2005; Muñoz et al., 2005), which is a limiting resource for breeding in this obligate cliffdweller (Ferguson-Lee and Christie, 2001). Despite their tendency to overestimate the best model (e.g. Márquez et al., 2011), AIC values provide strong support to the role that traditional agricultural land uses have on lanner falcon occupancy. The land-use model alone provided the best support to data and had the best performance. Among land uses, the extent of arable land and natural grassland and their interaction were selected as the best predictors of lanner falcon occupancy.

The Common Agricultural Policy was regarded as the principal culprit for the loss of biodiversity in Europe (Benton et al., 2003; Mattison and Norris, 2005). Nowadays, the reformed CAP for 2014-20 has still too much diluted environmental prescriptions to benefit biodiversity (Pe'er et al., 2014). Habitat modification, including the replacement of natural steppes and extensive cereal farmland with intensively-managed agricultural land, negatively affects nearly $70 \%$ of the priority species in Europe (Onrubia and Andrés, 2005; Sanderson et al., 2005). Agricultural land-use change in the study area is rapidly conforming to the agricultural intensification and land abandonment trends observed in Southern European countries (Sokos et al., 2013), as shown by the statistically significant increase in heterogeneous agricultural areas and shrubby vegetation associations, together with the decrease in natural grasslands in the short period of 2000-2006. The CLC class of 'heterogeneous agricultural areas' is formed by a juxtaposition of small parcels of diverse annual crops, pasture and/or permanent crops such as fruit, olive trees and vines (EEA, 2000), and is an expression of such agricultural intensification. Intensive olive cultivation threatens traditional agro-ecosystems such as winter cereals, extensively grazed pastures and low-input olive farming (Stoate et al., 2009). The replacement of the traditional mosaic landscape with intensive olive monocultures led to a substantial reduction of biodiversity (Siebert, 2004) with consequences for some threatened bird species (Santos and Cabral, 2003). In Sicily, vineyards are unfavourable habitats for bats (Di Salvo et al., 2009) and lesser kestrels (Falco naumanni) (Sarà, 2010), as well as for owls in Spain (Moreno-Mateos et al., 2011).

These land-use changes are increasingly transforming and eroding the extent of arable land within the study area, and consequently, the lanner falcon occupancy decreases, due to the interaction of arable land and heterogeneous areas. Fragmentation is another aspect of the heterogeneity arising from land abandon- ment and intensively cultivated open landscapes (EEA, 2011; Sokos et al., 2013). Fragmentation causes an increase in the number of CLC classes per every UTM cells of the study area and has a negative effect on lanner falcon occupancy. In the Iberian peninsula, abandonment results in loss and fragmentation of habitats for birds that require open farmland, such as lesser kestrel (Franco and Sutherland, 2004), little bustard (Tetrax tetrax) (Silva et al., 2004), calandra lark (Melanocorypha calandra) (Morgado et al., 2010). Agricultural land abandonment should not be assumed to benefit conservation, because the abundance of open-habitat bird species, often of higher conservation concern, tend to decrease significantly whereas the abundance of forest birds increases significantly (Sokos et al., 2013). In addition, land abandonment causes habitat encroachment, which in turn decreases the quantity of ecotonal habitats in the long term (Scozzafava and De Sanctis, 2006), and alters bird community patterns (Sirami et al., 2008). Thus, several resident and migrant species (larks, pipits, buntings, sparrows, thrushes, etc.) which are potential prey for the lanner falcon will find unsuitable habitats. In conclusion, would not be surprising that the interaction between the increase in heterogeneous areas and shrubby vegetation has a negative effect on lanner falcon occupancy, because very likely it decreases the species' profitability of hunting territories and foraging efficiency.

Finally, the presence of peregrine falcon constrains lanner occupancy. This issue would be exacerbated by some physical aspects of landscape, yet to be quantified; as shown by the intersection effect of peregrine and topography, which is much stronger than the single pure effects $(18.8 \%$ vs $6.9 \%$ and $1.1 \%$ respectively; see Fig. 1). The peregrine falcon is expanding in Sicily (Sarà, 2008) and a turn-over of sites has often been recorded, with peregrine falcons taking more lanner falcon sites than vice versa. The presence of potential competitors has been suggested as a possible limiting factor of territory occupancy (Carrete et al., 2005). Morphologically, peregrine and lanner falcons are very similar species (Ferguson-Lee and Christie, 2001) and this raises the possibility of interference competition for breeding and hunting territories, by restricting access of the lanner falcon to otherwise usable habitats (Jenkins and Hockey, 2001; Manzi and Perna, 1994).

The variation partitioning method selected factors of the greatest probable influence from among those analysed (Lobo et al., 2002), suggesting how the alteration of agricultural steppe-like habitats by abandonment and intensification might modify the population traits of ecologically equivalent species. For instance, afforestation of slopes and undulated lands (under EU Regulation 2080/92), and habitat encroachment by land abandonment would favour desertion and turn-over of sites, because lanner falcon tends to avoid cliffs on forested habitats (De Lisio, 2007). Such land-use changes would thus enhance the effect of the peregrine falcon in 
limiting lanner falcon occupancy, as the intersection effect between peregrine and land-uses (10.90\% in Fig. 1 ) revealed.

Models obtained in this study are useful for the management of lanner falcons in Mediterranean landscapes, because procedures used to evaluate the discrimination performance of models to data resulted in a relatively high level of correct classifications for the sites, and the analytical cartography based on favourability allowed mapping the realized distribution of lanners. Many favourable habitats for lanner falcon occupancy fall outside the regional N2000 network and less than $25 \%$ of the Sicilian population currently breeds within the existing networks. This occurs because large and solitary raptors have generally dispersed populations and large territories (Ferguson-Lee and Christie, 2001). In addition, pseudo-steppes and traditional agricultural habitats are not well represented in protected areas of Italy (Andreotti et al., 2008) and Spain (Abellán et al., 2011; De la Montaña et al., 2011) and this limits the efficiency of N2000 networks for the conservation of raptors living in agro-ecosystems (Díaz-Gómez et al., 2013).

Opportunities for the conservation of species whose distribution extends outside the N2000 networks could be represented by AES implemented on behalf of the Rural Development Programmes (De la Concha, 2005). This implies the necessity of promoting financial support for AES supporting lanner falcon conservation mainly in the most favourable areas of western and central Sicily. Mostly focused on farmland birds, only few AES have been currently targeted to meso-predator conservation, through implementation of actions favouring richness, density and accessibility of their prey (e.g. Arlettaz et al., 2010; Trierweiler et al., 2008); and none, to my knowledge, has so far involved top predators.

The scale of AES deployment might be the key factor for success of programmes promoting population persistence and dispersal processes of the lanner falcon. AES at landscape scale among collaborative farmers (McKenzie et al., 2013; Pe'er et al., 2014) are opportune for species of large habitat requirements and should aim to create a network of priority areas, based on the analytical cartography of environmental favourability; both in places where lanner pairs still live in safe conditions and in others where pairs are being exposed to habitat changes. In the first case, the goal would be the protection of unperturbed habitats; whereas in the second case, would be the maintenance of cereal steppes, favouring conversions to grassland, rotation and intercropping practices, while minimising anthropogenic interference and infrastructure building.

The development of AES for lanner falcons could have important conservation implications not only for the target-species per se, because should be necessary to involve the competitive peregrine falcon and other threatened steppe-like raptors like the Egyptian vulture (Neophron percnopterus; Sarà and Di Vittorio, 2003) and the Bonelli eagle (Aquila fasciata; Di Vittorio et al., 2012). In theory, landscape scale AES would benefit also preys of threatened predators of agro-ecosystems (Delibes-Mateos et al., 2009; Fernandez et al., 2006). Nevertheless, it is known that the same agricultural policy may be favourable for some species of conservation concern but detrimental to others (Reino et al., 2010), and complex interactions between species, such as interference competition, may often generate conflicts between conservation actions (Oro et al., 2009). Multi-species problems cannot be solved by local studies and single-species experts. Novel computational methods performing food web simulations (e.g., Livi et al., 2011; Jordán et al., 2012) can suggest key-species and interactions, providing quantitative priorities for conservation and supporting decision-making.

\section{Conclusion}

The main challenge of lanner falcon conservation in Sicily lies with measures at a wider spatial scale than the regional N2000 networks, and would thus be posited in the context of the EU Common Agricultural Policy. In addition to the commitment of AES operating at landscape scale, the use of large raptors, as focal AES species, would imply a further advance in conservation planning because top predators are effective surrogate species for biodiversity conservation (Cabeza et al., 2008; Sergio et al., 2005), as they support species richness, which in turn regulates and structures most ecosystems (Ritchie and Johnson, 2009; Sergio et al., 2008). A holistic ecosystem approach is therefore required, as more conceptually sound and efficient, and may provide multi-species solutions and more uniform benefits in conservation efforts.

\section{Acknowledgements}

I thank M. Di Vittorio, S. Falcone, S. Grenci, R. Mascara, B. Massa and L. Zanca for field support during monitoring and access to their databases. A. La Mantia and S. Triolo performed GIS operations. J.M. Lobo, R. Real and two anonymous referees provided useful comments to an earlier draft of the manuscript. This project was supported by the Italian Ministry of Education, University and Research (PRIN 2010-2011, 20108 TZKHC).

\section{Appendix A. Supplementary material}

Supplementary data associated with this article can be found, in the online version, at http://dx.doi.org/10.1016/j.biocon.2014.08. 004.

\section{References}

AA.VV., 2008. Atlante della Biodiversità della Sicilia: Vertebrati terrestri. Arpa Sicilia, Palermo, Italy.

Abellán, M.D., Martínez, J.E., Palazón, J.A., Esteve, M.A., Calvo, J.A., 2011. Efficiency of a protected-area network in a mediterranean region: a multispecies assessment with raptors. Environ. Manage. 47, 83-991.

Abuladze, A., Eligulashvili, V., Rostiashvili, G, 1991. On status of Lanner in Soviet Union. Materials of the $10^{\text {th }}$ All-Union Ornithological Conference Navuka $i$ tekhnika. Minsk, Belarus Part 2, Book 2, 26-28.

Acevedo, P., Real, R., 2012. Favourability: concept, distinctive characteristics and potential usefulness. Naturwissenschaften 99, 515-522.

Akaike, H., 1973. Information theory and an extension of the maximum likelihood principle. In: Petrov, B.N., Csaki, F. (Eds.), Second International Symposium on Information Theory. Akademiai Kiado, Budapest, pp. 267-281.

Andreotti, A., Leonardi, G., 2007. Piano d'azione nazionale per il Lanario (Falco biarmicus feldeggi). Quaderni Conservazione Natura. Ministero Ambiente 24, 1 109.

Andreotti, A., Leonardi, G., Sarà, M., Brunelli, M., De Lisio, L., De Sanctis, A., Magrini, M., Nardi, R., Perna, P., Sigismondi, A., 2008. Landscape-scale spatial distribution of the lanner falcon (Falco biarmicus feldeggii) breeding population in Italy Ambio 37, 443-447.

APAT, 2005. La realizzazione in Italia del progetto europeo Corine Land Cover 2000 APAT Report No36, Rome, Italy.

Arlettaz, R., Krähenbühl, M., Almasi, B., Roulin, A., Schaub, M., 2010. Wildflower areas within revitalized agricultural matrices boost small mammal populations but not breeding Barn Owls. J. Ornithol. 151, 553-564.

Austin, G.E., Thomas, C.J., Houston, D.C., Thompson, D.B.A., 1996. Predicting spatial distribution of Buzzard Buteo buteo nesting areas using a geographical information system and remote sensing. J. Appl. Ecol. 33, 1451-1550.

Balbontìn, J., 2005. Identifying suitable habitat for dispersal in Bonelli's eagle: an important issue in halting its decline in Europe. Biol. Conserv. 126, 74-86.

Balmford, A., Carey, P., Kapos, V., Manica, A., Rodrigues, A.S.L., Scharlemann, J.P.W. 2009. Capturing the many dimensions of threat: comment on Salafsky et al. Conservat. Biol. 23, 482-487.

Barbosa, A.M., Real, R., Muñoz, A.R., Brown, J.A., 2013. New measures for assessing model equilibrium and prediction mismatch in species distribution models. Divers. Distrib. 19, 1333-1338.

Batáry, P., Báldi, A., Kleijn, D., Tscharntke, T., 2011. Landscape-moderated biodiversity effects of agri-environmental management: a meta-analysis. Proc. R. Soc. Lond. B 278, 1894-1902.

Benton, T.G., Vickery, J.A., Wilson, J.D., 2003. Farmland biodiversity: is habitat heterogeneity the key? Trends Ecol. Evolut. 18, 182-188.

Blondel, J., Aronson, J., 1999. Biology and Wildlife of the Mediterranean Region. Oxford University Press, New York.

BirdLife International, 2004. Birds in Europe. Population estimates, trends and conservation status. BirdLife International. Cambridge, UK.

Brambilla, M., Guidali, F., Negri, I., 2008. The importance of an agricultural mosaic for Cirl Buntings Emberiza cirlus in Italy. Ibis 150, 628-632. 
Brotons, L., Mañosa, S., Estrada, J., 2004. Modelling the effect of irrigation schemes on the distribution of steppe birds in Mediterranean farmland. Biodiversity Conservat. 13, 1039-1058.

Broyer, J., Curtet, L., Chazal, R., 2014. How to improve agri-environment schemes to achieve meadow bird conservation in Europe? a case study in the Saône valley, France. J. Ornithol. 155, 145-155.

Burnham, K., Anderson, D., 2002. Model Selection and Multimodel Inference: A Practical Information-Theoretic Approach, second ed. Springer-Verlag, New York.

Bustamante, J., Seoane, J., 2004. Predicting the distribution of four species of raptors (Aves: Accipitridae) in southern Spain: statistical models work better than existing maps. J. Biogeogr. 31, 295-306.

Butler, S.J., Boccaccio, L., Gregory, R.D., Vorisek, P., Norris, K., 2010. Quantifying the impact of land-use change to European farmland bird populations. Agric. Ecosyst. Environ. 137, 348-357.

Cabeza, M., Arponen, A., Van Teeffelen, A., 2008. Top predators: hot or not? a call for systematic assessment of biodiversity surrogates. J. Appl. Ecol. 45, 976-980.

Carrete, M., Sánchez-Zapata, J.A., Calvo, J.F., Lande, R., 2005. Demography and habitat availability in territorial occupancy of two competing species. Oikos $108,125-136$.

Carrete, M., Grande, J.M., Tella, J.L., Sànchez-Zapata, J.A., Donàzar, J.A., Dìaz-Delgado, R., Romo, A., 2007. Habitat, human pressure, and social behavior: partialling out factors affecting large-scale territory extinction in an endangered vulture. Biol. Conserv. 136, 143-154

Ciaccio, A., Dimarca, A., Lo Valvo, F., Siracusa, M., 1989. Primi dati sulla biologia e lo status del Lanario (Falco biarmicus) in Sicilia. Supplementi Ricerche Biologia Selvaggina $12,45-55$.

Clavero, M., Brotons, L., 2010. Functional homogenization of bird communities along habitat gradients: accounting for niche multidimensionality. Glob. Ecol. Biogeogr. 19, 684-696.

Conroy, M.J., Carroll, J.P., 2009. Quantitative Conservation of Vertebrates. WileyBlackwell, Oxford, UK.

De la Concha, I., 2005. The Common Agricultural policy and the role of rura development programmes in the conservation of steppe birds. In: Bota, G., Morales, M.B., Mañosa, S., Camprodon, J. (Eds.), Ecology and conservation of steppe-land birds, Lynx Edicions and Centre Tecnologic Forestal de Catalunya. Barcelona, Spain, pp. 237-252.

De la Montaña, E., Rey-Benayas, J.M., Vasques, A., Razola, I., Cayuela, L., 2011 Conservation planning of vertebrate diversity in a mediterranean agriculturaldominant landscape. Biol. Conserv. 144, 2468-2478.

Delibes-Mateos, M., Farfan, M.A., Olivero, J., Marquez, A.L., Vargas, J.M., 2009. Longterm changes in game species over a long period of transformation in the Iberian Mediterranean landscape. Environ. Manage. 43, 125-1268.

De Lisio L., 2007. Indici di qualità ambientale delle comunità ornitiche nidificanti in Molise. PhD thesis. Università degli Studi del Molise, Italy.

Díaz-Gómez, D.L., Toxopeus, A.G., Groen, T.A., Muñoz, A.R., Skidmore, A.K., Real, R. 2013. Measuring the insecurity index of species in networks of protected areas using species distribution modeling and fuzzy logic: the case of raptors in Andalusia. Ecol. Ind. 26, 174-182.

Di Salvo, I., Russo, D., Sarà, M., 2009. Habitat preferences of bats in a rural area of Sicily determined by acoustic surveys. Hystrix Italian J. Mammalogy 20, $137-$ 146.

Di Vittorio, M., 2007. Biologia e conservazione di cinque specie di uccelli rapaci in Sicilia. PhD thesis. Università di Palermo, Italy.

Di Vittorio, M., Sarà, M., López-López, P., 2012. Habitat preferences of Bonelli’s Eagles Aquila fasciata in Sicily. Bird Study 59, 207-217.

Donald, P.F., Green, R.E., Heath, M.F., 2001. Agricultural intensification and the collapse of Europe's farmland bird populations. Proc. Royal Soc. B: Biol. Sci. 268 25-29.

EEA - European Environmental Agency, 2000. Corine Land Cover Technical guide Addendum 2000. <http://www.eea.eu.int> (accessed 10.11.13).

EEA - European Environmental Agency, 2011. Landscape fragmentation in Europe European Environment Agency report n. 2, Copenhagen. European Commission, 2000. Managing Natura 2000 sites: The provisions of Article 6 of the 'Habitats' Directive 92/43/EEC. Office for Official Publications of the European Communities. Luxembourg.

European Commission, 2005. Agri-environment Measures Overview on General Principles, Types of Measures, and Application. Office for Official Publications of the European Communities. Luxembourg.

European Commission, 2006. Halting the loss of Biodiversity by 2010 - and beyond sustaining Ecosystem services for Human Well-Being. <http://ec.europa.eu environment/> (accessed 1.12.13).

Elith, J., Leathwick, J.R., 2009. Species distribution models: ecological explanation and prediction across time. Ann. Rev. Ecol., Evolut. Syst. 40, 677-697.

Ferguson-Lee, J., Christie, D.A., 2001. Raptors: Birds of Prey of the World. A. \& C Black Publishing, London, UK.

Fernandez, N., Delibes, M., Palomares, F., 2006. Landscape evaluation in conservation: molecular sampling and habitat modeling for the Iberian lynx Ecol. Appl. 16, 1037-1049.

Fonderflick, J., Lepart, J., Caplat, P., Debussche, M., Marty, P., 2010. Managing agricultural change for biodiversity conservation in a Mediterranean upland. Biol. Conserv. 143, 737-746.

Forman, R.T.T., 1995. Land Mosaics: The Ecology of Landscapes and Regions. Cambridge University Press, Cambridge, UK.
Foster, D., Swanson, F., Aber, J., Burke, I., Brokaw, N., Tilman, D., 2003. The importance of land-use legacies to ecology and conservation. Bioscience 53, 77 88.

Franco, A.M., Sutherland, W.J., 2004. Modelling the foraging habitat selection of lesser kestrels: conservation implications of European agricultural policies. Biol. Conserv. 120, 63-74.

Franklin, J., 2009. Mapping Species Distributions: Spatial Inference and Prediction. Cambridge University Press, Cambridge, UK.

Goriup, P.D., 1988. Ecology and Conservation of Grassland Birds. ICPB Technical Publication, Cambridge, UK, n. 7.

Green, R.E., Cornell, S.J., Scharlemann, J.P.W., Balmford, A., 2005. Farming and the fate of wild nature. Science 307, 550-555.

Gregory, R.D., Baillie, S.R., 1998. Large scale habitat use of some declining British birds. J. Appl. Ecol. 35, 785-799.

Grenci, S., Di Vittorio, M., 2004. Alimentazione del lanario Falco biarmicus feldeggii in Sicilia. Avocetta 28, 93-95.

Grosbois, V., Gimenez, O., Gaillard, J.M., Pradel, R., Barbraud, C., Clobert, J., Møller, P., Weimerskirch, H., 2008. Assessing the impact of climate variation on survival in vertebrate populations. Biol. Rev. 83, 357-399.

Guisan, A., Zimmermann, N.E., 2000. Predictive habitat distribution models in ecology. Ecol. Model. 135, 147-186.

Guisan, A., Thuiller, W., 2005. Predicting species distributions: offering more that simple habitat models. Ecol. Lett. 8, 993-1009.

Hiron, M., Berg, T., Eggers, S., Josefsson, J., Pärt, T., 2013. Bird diversity relates to agrienvironment schemes at local and landscape level in intensive farmland. Agric. Ecosyst. Environ. 176, 9-16.

Hosmer, D., Lemeshow, S., 2000. Applied Logistic Regression Analysis. Wiley and Sons, New York, USA.

Jenkins, A.R., Hockey, P.A.R., 2001. Prey availability influences habitat tolerance: an explanation for the rarity of peregrine falcons in the tropics. Ecography 24, 353367.

Jiménez-Valverde, A., Lobo, J.M., Hortal, J., 2008. Not as good as they seem: the importance of concepts in species distribution modelling. Diversity Distrib. http://dx.doi.org/10.1111/j.1472-4642.2008.00496.x.

Jordán, F., Gjata, N., Mei, S., Yule, C.M., 2012. Simulating food web dynamics along a gradient: quantifying human influence. PLoSONE 7. http://dx.doi.org/10.1371/ journal.pone.0040280.

Keitt, T.H., Bjornstad, O.N., Dixon, P.M., Citron-Pousty, S., 2002. Accounting for spatial pattern when modelling organism-environment interactions. Ecography 25, 616-625.

Kleijn, D., Sutherland, W.J., 2003. How effective are agri-environment schemes in conserving and promoting biodiversity? J. Appl. Ecol. 40, 947-969.

Kovács-Hostyánszki, A., Báldi, A., 2012. Set-aside fields in agri-environment schemes can replace the market-driven abolishment of fallows. Biol. Conserv. $152,196-203$

Lane, S.J., Alonso, J.C., Martin, C.A., 2001. Habitat preferences of great bustard Otis tarda flocks in the arable steppes of central Spain: are potentially suitable areas unoccupied? J. Appl. Ecol. 38, 193-203.

Legendre, P., Legendre, L., 1998. Numerical Ecology. Elsevier Science, Amsterdam, Netherlands.

Legendre, P., Dale, M.R.T., Fortin, M.J., Casgrain, P., Gurevitch, J., 2004. Effects of spatial structures on the results of field experiments. Ecology 85, 3202-3214.

Livi, C.M., Jordán, F., Lecca, P., Okeyet, T.A., 2011. Identifying key species in ecosystems with stochastic sensitivity analysis. Ecol. Model. 222, 2542-2551.

Lobo, J.M., Lumaret, J.P., Jay-Robert, P., 2002. Modelling the species richness distribution of French dung beetles (Coleoptera, Scarabaeidae) and delimiting the predictive capacity of different groups of explanatory variables. Glob. Ecol. Biogeogr. 11, 265-277.

López-López, P., García-Ripollés, C., Soutullo, Á., Cadahía, L., Urios, V., 2007a. Identifying potentially suitable nesting habitat for golden eagles applied to important bird areas' design. Anim. Conserv. 10, 208-218.

López-López, P., García-Ripollés, C., Soutullo, A., Cadahía, L., Urios, V., 2007b. Are important bird areas and special protected areas enough for conservation? the case of Bonelli's eagle in a Mediterranean area. Biodivers. Conserv. 16, 37553780.

Manly, B.F.J., McDonald, L.L., Thomas, D.L., McDonald, T.L., Erickson, W.P., 2002. Resource Selection by Animals: Statistical Design and Analysis for Field Studies, second ed. Kluwer, Dordrecht.

Manzi, A., Perna, P., 1994. Relationships between peregrine and lanner in the Marches (central Italy). In: Meyburg, B.-U., Chancellor, R.D. (Eds.), Raptor Conservation Today. WWGBP, Berlin, Germany, pp. 157-162.

Márquez, A.L., Real, R., Olivero, J., Estrada, A., 2011. Combining climate with other influential factors for modelling the impact of climate change on species distribution. Climatic Change 108, 135-157.

Martínez, J.A., Serrano, D., Zuberogoitia, I., 2003. Predictive models of habitat preferences for the Eurasian eagle owl Bubo bubo. A multiscale approach. Ecography 26, 21-28.

Massa, B., Lo Valvo, F., Siracusa, M., Ciaccio, A., 1991. Il Lanario (Falco biarmicus feldeggii Schlegel), in Italia: status, biologia e tassonomia. Naturalista siciliano $15,27-63$

Mattison, E.H.A., Norris, K., 2005. Bridging the gaps between agricultural policy, land-use and biodiversity. Trends Ecol. Evol. 20, 610-616.

McCullagh, P., Nelder, J.A., 1989. Generalized Linear Models. Chapman and Hall/CRC, London, UK. 
McGarigal, K., Marks, B.J., 1995. Fragstats. Spatial Pattern. Analysis Program for quantifying landscape structure. <http://www.umass.edu/landeco/pubs/ mcgarigal.marks.1995.pdf>.

McKenzie, A.J., Emery, S.B., Franks, J.R., Whittingham, M.J., 2013. Landscape-scale conservation: collaborative agri-environment schemes could benefit both biodiversity and ecosystem services, but will farmers be willing to participate? J. Appl. Ecol. 50, 1274-1280.

Montgomery, D.C., Peck, E.A., 1982. Introduction to Regression Analysis. Wiley, New York, USA.

Moreno-Mateos, D., Rey Benayas, J.M., Pérez-Camacho, L., de la Montaña, E., Rebollo, S., Cayuela, L., 2011. Effects of land use on nocturnal birds in a Mediterranean agricultural landscape. Acta Ornithologica 46, 173-182.

Morgado, R., Beja, P., Reino, L., Gordinho, L., Delgado, A., Borralho, R., 2010. Calandra lark habitat selection: strong fragmentation effects in a grassland specialist. Acta Oecologica 36, 63-73.

Muñoz, A.R., Real, R., Barbosa, A.M., Vargas, J.M., 2005. Modelling the distribution of Bonelli's eagle in Spain: implications for conservation planning. Diversity Distrib. 11, 477-486.

Murtaugh, P.A., 2009. Performance of several variable-selection methods applied to real ecological data. Ecol. Lett. 12, 1061-1068.

Myers, N., Mittermeier, R.A., Mittermeier, C.G., da Fonseca, G.A.B., Kent, J., 2000. Biodiversity hotspots for conservation priorities. Nature 403, 853-858.

Onrubia, A., Andrés, T., 2005. Impact of human activities of steppic-land birds: a review in the context of the Western Palaearctic. In: Bota, G., Morales, M.B., Mañosa, S., Camprodon, J. (Eds.), Ecology and conservation of steppe-land birds, Lynx Edicions and Centre Tecnologic Forestal de Catalunya. Barcelona, Spain, pp. 185-210.

Oro, D., Pérez-Rodríguez, A., Martínez-Vilalta, A., Bertolero, A., Vidald, F., Genovart, M., 2009. Interference competition in a threatened seabird community: a paradox for a successful conservation. Biol. Conserv. 142, 1830-1835.

Pain, D.J., Pienkowski, M.W., 1997. Farming and Birds in Europe: The Common Agricultural Policy and its Implications for Bird Conservation. Academic Press, London, UK.

Pearce, J., Ferrier, S., 2000. An evaluation of alternative algorithms for fitting species distribution models using logistic regression. Ecol. Model. 128, 127147.

Pe'er, G., Dicks, L.V., Visconti, P., Arlettaz, R., Báldi, A., Benton, T.G., Collins, S., Dieterich, M., Gregory, R.D., Hartig, F., Henle, K., Hobson, P.R., Kleijn, D., Neumann, R.K., Robijns, T., Schmidt, J., Shwartz, A., Sutherland, W.J., Turbé, A., Wulf, F., Scott, A.V., 2014. EU agricultural reform fails on biodiversity. Science 344, 1090-1092.

Poirazidis, K., Goutner, V., Skartsi, T., Stamou, G., 2004. Modelling nesting habitat as a conservation tool for the Eurasian black vulture (Aegypius monachus) in Dadia Nature Reserve, northeastern Greece. Biol. Conserv. 118, 235-248.

Pressey, R.L., Bottrill, M.C., 2009. Approaches to landscape- and seascape-scale conservation planning: convergence, contrasts, and challenges. Oryx 43, 464 475 .

Pywell, R.F., Heard, M.S., Bradbury, R.B., Hinsley, S., Nowakowski, M., Walker, K.J., Bullock, J.M., 2012. Wildlife-friendly farming benefits rare birds, bees and plants. Biol. Lett. 8, 772-775.

Real, R., Barbosa, A.M., Vargas, J.M., 2006. Obtaining environmental favourability functions from logistic regression. Environ. Ecol. Stat. 13, $237-$ 245.

Reino, L., Porto, M., Morgado, R., Moreira, F., Fabião, A., Santana, J., Delgado, A., Gordinho, L., Cal, J., Beja, P., 2010. Effects of changed grazing regimes and habitat fragmentation on Mediterranean grassland birds. Agric. Ecosyst. Environ. 138, 27-34.

Rempel, R.S., Carr, A.P., Kaukinen, D., 2008. Patch Analyst extension for ArcMap: v. 4.2. Ontario Ministry Natural Resources. http://flash.lakeheadu.ca/ $\simeq$ rrempel/ patch.

Ritchie, E.G., Johnson, C.N., 2009. Predator interactions, mesopredator release and biodiversity conservation. Ecol. Lett. 12, 982-998.

Rivas-Martínez, S., 1988. Memoria del Mapa de Series de Vegetación de España 1:400.000. ICONA, Madrid, Spain.

Rodríguez, J.P., Brotons, L., Bustamante, J., Seoane, J., 2007. The application of predictive modelling of species distribution to biodiversity conservation. Diversity Distrib. 13, 243-251.
Rounsevell, M.D.A., Reginster, I., Araújo, M.B., Carter, T.R., Dendoncker, N., Ewert, F. House, J.I., Kankaanpää, S., Leemans, R., Metzger, M.J., Schmit, C., Smith, P., Tuck, G., 2006. A coherent set of future land use change scenarios for Europe. Agric. Ecosyst. Environ. 114, 57-68.

Sanderson, E.W. Redford, K.H., Vedder, A, Coppolillo, P.B, Ward, S.E, 2002. A conceptual model for conservation planning based on landscape species requirements. Landscape Urban Plann. 58, 41-56.

Sanderson, F.J., Donald, P.F., Burfield, I.J., 2005. Farmland birds in Europe: from policy change to population decline and back again. In: Bota, G., Morales, M.B. Mañosa, S., Camprodon, J. (Eds.), Ecology and conservation of steppe-land birds Lynx Edicions and Centre Tecnologic Forestal de Catalunya. Barcelona, Spain pp. 211-236.

Santos, M., Cabral, J.A., 2003. Development of a stochastic dynamic model for ecological indicators' prediction in changed Mediterranean agroecosystems of north-eastern Portugal. Ecol. Ind. 3, 285-303.

Sarà, M., 2008. Breeding abundance of threatened raptors as estimated from occurrence data. Ibis $150,766-778$.

Sarà, M., 2010. Climate and land-use changes as determinants of Lesser Kestrel Falco naumanni abundance in Mediterranean cereal steppes (Sicily). Ardeola 57, 3 22.

Sarà, M., Di Vittorio, M., 2003. Factors influencing the distribution, abundance and nest site selection of an endangered Egyptian vulture (Neophron percnopterus) population in Sicily. Anim. Conserv. 6, 317-328.

SCIA, 2008. Sistema nazionale per la raccolta, elaborazione e diffusione di dat Climatologici di Interesse Ambientale. <http://www.scia.sinanet.apat.it/ sciaweb/> (accessed 4.04.12).

Scozzafava, S., De Sanctis, A., 2006. Exploring the effects of land abandonment on habitat suitability for three passerine species in a highland area of Central Italy Landscape Urban Plann. 75, 23-33.

Segurado, P., Araújo, M.B., Kunin, W.E., 2006. Consequences of spatial autocorrelation for niche-based models. J. Appl. Ecol. 43, 433-444.

Sergio, F., Newton, I., Marchesi, L., 2005. Top predators and biodiversity. Nature 436, 192.

Sergio, F., Caro, T., Brown, D., Clucas, B., Hunter, J., Ketchum, J., McHugh, K., Hiraldo F., 2008. Top predators as conservation tools: ecological rationale, assumptions, and efficacy. Ann. Rev. Ecol., Evolut. Syst. 39, 1-19.

Siebert, S.F., 2004. Traditional agriculture and the conservation of biological diversity in Crete, Greece. Int. J. Agric. Sustainability 2, 109-117.

Silva, J.P., Pinto, M., Palmeirim, J.M., 2004. Managing landscapes for the little bustard Tetrax tetrax: lessons from the study of winter habitat selection. Biol. Conserv. 117, 521-528.

Sirami, C., Brotons, L., Burfield, I., Fonderflick, J., Martin, J.L., 2008. Is land abandonment having an impact on biodiversity? A meta-analytical approach to bird distribution changes in the north-western Mediterranean. Biol. Conserv. 141, 450-459.

Soberón, J., 2007. Grinnellian and Eltonian niches and geographic distribution of species. Ecol. Lett. 10, 1115-1123.

Sokos, C.K., Mamolos, A.P., Kalburtji, K.L., Birtsas, P.K., 2013. Farming and wildlife in Mediterranean agroecosystems. J. Nat. Conserv. 21, 81-92.

Stoate, C., Baldi, A., Beja, P., Boatman, N.D., Herzon, I., van Doorn, A., 2009. Ecologica impacts of early 21st century agricultural change in Europe - a review. J. Environ. Manage. 91, 22-46.

Sutherland, W.J., 2004. A blueprint for the countryside. Ibis 146, 230-238.

Thuiller, W., 2003. Optimizing predictions of species distributions and projecting potential future shifts under global change. Glob. Change Biol. 9, 1353-1362.

Trierweiler, C., Drent, R.H., Komdeur, J., Exo, K.-M., Bairlein, F., Koks, B.J., 2008. The annual cycle of Montagu's Harrier Circus pygargus: driven by voles and grasshoppers. Limosa 81, 107-115.

Whittingham, M.J., 2007. Will agri-environment schemes deliver substantial biodiversity gain, and if not why not? J. Appl. Ecol. 44, 1-5.

Whittingham, M.J., 2011. The future of agri-environment schemes: biodiversity gains and ecosystem service delivery? J. Appl. Ecol. 48, 509-513.

Whittingham, M.J., Stephens, P.A., Bradbury, R.B., Freckleton, R.P., 2006. Why do we still use stepwise modelling in ecology and behaviour? J. Anim. Ecol. 75, 1182 1189.

Zamora, J., Verdú, J.R., Galante, E., 2007. Species richness in Mediterranean agroecosystems: spatial and temporal analysis for biodiversity conservation. Biol. Conserv. 134, 113-121. 